\title{
Penegakan Hukum Pidana Perusahaan yang Tidak Memenuhi Kewajibannya dalam Program Badan Penyelenggara Jaminan Sosial
}

\author{
Didik Lestariyono ${ }^{1}$ Bambang Sugiri ${ }^{2}$ Rachmad Syafa'at ${ }^{3}$ \\ ${ }^{1}$ Didik Lestariyono; Fakultas Hukum Universitas Brawijaya; Malang; 65145; Indonesia. \\ ${ }^{2}$ Bambang Sugiri; Fakultas Hukum Universitas Brawijaya; Malang; 65145; Indonesia. \\ ${ }^{3}$ Rachmad Syafa'at; Fakultas Hukum Universitas Brawijaya; Malang; 65145; Indonesia.
}

\section{ARTICLEINFO}

Article history:

Received 2019-09-09

Received in revised form

2019-10-19

Accepted 2019-12-01

Kata kunci:

Penegakan Hukum; Perusahaan;

Program BPJS.

Keywords:

Law Enforcemen; Companies; The BPJS.

DOI: https://doi.org/10.26905/

idjch.v10i2.3225.
Corresponding Author:

* Didik Lestariyono.

E-mail address: didik.lestariyono@gmail.com

\section{Abstrak}

Terjadi kesenjangan antara das sollen dan das sein. Das sollen (peraturan hukum) dalam Pasal 19 ayat (1) dan ayat (2) jo. Pasal 55 UU BPJS memberikan sanksi pidana kepada perusahaan yang tidak membayarkan iuran BPJS pekerjanya. Namun, das sein (kenyataannyalperistiwa yang terjadi di masyarakat) perusahaan tidak dikenakan sanksi pidana walaupun secara unsur-unsur pidana dalam UU BPJS telah terpenuhi. Penelitian ini menggunakan metode yuridis empiris dengan pendekatan yuridis sosiologis. Kesimpulan penelitian ini adalah 1) Faktor penyebab perusahaan tidak memenuhi kewajiban sebagai peserta dalam program dikarenakan tidak disiplinnya perusahaan dalam mengelola keuangan yang seharusnya digunakan sebagai iuran program BPJS pekerjanya dan dikarenakan stakeholder terkait hanya memberikan sanksi administratif kepada perusahaan. 2) Implikasi hukum bagi perusahaan ialah dikenakan sanksi administratif. 3) Upaya penegakan hukum yang dilakukan aparat penegak hukum terhadap perusahaan yang tidak memenuhi kewajibannya dalam program BPJS di Kabupaten Malang ialah pengenaan sanksi pidana.

\begin{abstract}
There is a gap between das sollen and das sein. Das sollen (legal regulations) in Article 19 paragraph (1) and paragraph (2) jo. Article 55 of the BPJS Law provides criminal sanctions to companies that do not pay BPJS contributions to their workers. However, das sein (in fact / events that occur in the community) companies are not subject to criminal sanctions even though the criminal elements in the BPJS Law have been fulfilled. This study uses an empirical juridical method with a sociological juridical approach. The conclusions of this study are 1) Factors that cause companies not fulfilling their obligations as participants in the program due to the company's lack of discipline in managing finances which should be used as contributions to BPJS program workers and because the relevant stakeholders only provide administrative sanctions to companies. 2) The legal implication for companies
\end{abstract}


is that they are subject to administrative sanctions. 3) Law enforcement efforts carried out by law enforcement officers against companies that do not fulfill their obligations in the BPJS program in Malang Regency are the imposition of criminal sanctions.

\section{Latar Belakang}

Kabupaten Malang merupakan salah satu daerah di Jawa Timur dengan potensi sektor industri dan perdagangan yang besar. Penyebabnya ialah kontribusi sektor industri dan perdagangan terhadap perekonomian Kabupaten Malang dalam Produk Domestik Regional Bruto tahun 1999 sektor industri menyumbang 15,2\% dan perdagangan sebesar $22,4 \%$ sehingga berjumlah $37,6 \%$, sementara sektor pertanian sebesar $35,2 \%$ sektor jasa 12,4\% dan 6 sektor lainnya 14,8\% (Portal Pemerintah Kabupaten Malang, 2018).

Jumlah perusahaan di Kabupaten Malang berdasarkan Sensus Ekonomi 2016 tercatat sebanyak 261.737 usaha/perusahaan non pertanian yang dikelompokkan dalam 17 kategori lapangan usaha sesuai dengan Klasifikasi Baku Lapangan Usaha Indonesia (KBLI) 2015 (Badan Pusat Statistik Kabupaten Malang, 2017). Namun potensi yang besar di Kabupaten Malang tersebut juga menyisakan permasalahan dalam implementasi UU BPJS baik BPJS Kesehatan maupun BPJS Ketenagakerjaan. Salah satunya ialah perusahaan yang terdaftar menjadi peserta BPJS Ketenagakerjaan setidaknya mencapai 2.851 perusahaan di tahun 2016 (Badan Pusat Statistik Kabupaten Malang, 2017).

Menurut Molengraff, dari sudut ekonomi pengertian perusahaan adalah keseluruhan perbuatan yang dilakukan secara terus menerus, bertindak keluar, untuk memperoleh penghasilan, dengan cara memperdagangkan atau menyerah- kan barang atau mengadakan perjanjian perdagangan (Muhammad, 2006). Perusahaan dalam UU BPJS termasuk dalam pengertian Pemberi Kerja, adapun Pemberi Kerja ialah orang perseorangan, pengusaha, badan hukum, atau badan lainnya yang memperkerjakan tenaga kerja atau penyelenggara negara yang mempekerjakan pegawai negeri dengan membayar gaji, upah, atau imbalan dalam bentuk lainnya.

Perusahaan sebagai pemberi kerja secara bertahap wajib mendaftarkan dirinya dan pekerjanya sebagai peserta kepada BPJS sesuai dengan Program Jaminan Sosial yang diikuti. Berdasarkan Pasal 17 UU BPJS, perusahaan yang tidak mendaftarkan dirinya dan pekerjanya akan dikenakan sanksi administratif antara lain teguran tertulis, denda dan/atau tidak mendapat pelayanan tertentu.

Tanpa memperhatikan kearifan lokal, berbagai kebijakan akan menjadi timpang, dan kurang akomodatif (Syafa'at, 2008). Diterapkannya sanksi administratif kepada perusahaan yang tidak mendaftarkan dalam BPJS dikarenakan tidak efektifnya pencantuman sanksi pidana pada peraturan sebelumnya, tujuan pencantuman yang harapannya untuk memberikan perlindungan hukum kepada pekerja, justru mengancam keberlangsungan hubungan kerja antara pekerja dengan perusahaan (Hitaningtyas, 2017). Penghapusan sanksi pidana sesuai dengan tujuan penyelenggaraan jaminan sosial, yaitu untuk mendapatkan kepesertaan yang sebanyak-banyaknya sebagai wujud dari hak konstitusional warga Negara. 


\section{Jurnal Cakrawala Hukum, Volume 10 No. 2 Desember 2019}

ISSN PRINT 2356-4962 ISSN ONLINE 2598-6538

Perusahaan yang telah menjadi peserta BPJS, berdasarkan Pasal 19 ayat (1) dan ayat (2) UU BPJS, perusahaan berkewajiban untuk:

(1) Pemberi Kerja wajib memungut iuran yang menjadi beban Peserta dari Pekerjanya dan menyetorkannya kepada BPJS.

(2) Pemberi Kerja wajib membayar dan menyetor Iuran yang menjadi tanggung jawabnya kepada BPJS.

Kedua pasal tersebut perusahaan yang sudah menjadi peserta BPJS wajib untuk memungut iuran, membayar dan menyetor iuran yang menjadi beban peserta dari pekerjanya kepada BPJS. Dalam UU BPJS memberikan sanksi pidana bagi perusahaan yang melanggar Pasal 19 ayat (1) dan ayat (2) yang diatur dalam Pasal 55 UU BPJS. Adapun bunyi pasal 55 UU BPJS antara lain:

"Pemberi Kerja yang melanggar ketentuan sebagaimana dimaksud dalam Pasal 19 ayat (1) atau ayat (2) dipidana dengan pidana penjara paling lama 8 (delapan) tahun atau pidana denda paling banyak Rp. 1.000.000.000,00 (satu miliar rupiah)."

Terlihat bahwa UU BPJS sangat ketat dalam menertibkan perusahaan untuk melaksanakan Pasal 19 ayat (1) dan ayat (2) yang menjadi kewajibannya setelah menjadi peserta BPJS. Namun, di Kabupaten Malang setidaknya terdapat 60\% perusahaan yang tidak disiplin membayar BPJS bagi pekerjanya baik BPJS Ketenagakerjaan maupun BPJS Kesehatan (JatimTimes, 2018). Menurut Kepala Bidang (Kabid) Hubungan Industrial Disnaker Kabupaten Malang sekitar 1.200 perusahaan yang tidak taat bayar BPJS, mayoritas perusahaan berskala kecil hingga menengah (Malang Post, 2018).

Penegakan hukum pidana terhadap perusahaan yang telah mendaftarkan pekerjanya dalam program BPJS tetapi tidak memenuhi kewajibannya. Kewajiban perusahaan yang telah mendaftarkan pekerjanya sebagai peserta BPJS termuat dalam Pasal 19 ayat (1) dan ayat (2) UU BPJS yakni memungut, membayar dan menyetor iuran BPJS. Alasan penulis ialah karena jika dilihat secara langsung, 1.200 perusahaan di Kabupaten Malang telah melanggar Pasal 19 ayat (1) dan ayat (2) jo. Pasal 55 UU BPJS yang seharusnya dikenakan sanksi pidana sesuai dengan UU BPJS.

Sehingga, isu hukum dalam penelitian ini ialah terjadi kesenjangan antara das sollen dan das sein. Das sollen (peraturan hukum) dalam Pasal 19 ayat (1) dan ayat (2) jo. Pasal 55 UU BPJS memberikan sanksi pidana kepada perusahaan yang tidak membayarkan iuran BPJS pekerjanya. Namun, das sein (kenyataannya/peristiwa yang terjadi di masyarakat) perusahaan tidak dikenakan sanksi pidana walaupun secara unsur-unsur pidana dalam UU BPJS telah terpenuhi. Penulis mengkaji isu hukum tersebut dikaitkan dengan rasa keadilan, kepastian hukum dan kemanfaatan dalam penegakan sanksi pidana UU BPJS baik kepada perusahaan maupun pekerjanya.

Berdasarkan latar belakang tersebut di atas, perlu dilakukan kajian mendalam tentang kesenjangan antara das sollen dan das sein dalam penegakan hukum pidana bagi perusahaan yang tidak memenuhi kewajibannya dalam program BPJS di Kabupaten Malang. Penulis melihat adanya perusahaan di Kabupaten Malang yang tidak melakukan kewajibannya berupa memungut dan menyetorkan iuran BPJS. Hal ini mengakibatkan pekerja yang dirugikan karena tidak dapat memperoleh jaminan sosial baik berupa jaminan kesehatan dan jaminan ketenagakerjaan.

Berdasarkan uraian latar belakang di atas, penulis merumuskan beberapa permasalahan diantaranya adalah sebagai berikut: 1) Mengapa perusahaan yang tidak memenuhi kewajibannya dalam program BPJS di Kabupaten Malang tidak dikenakan sanksi pidana dalam UU BPJS? 2) Apa implikasi hukum terhadap perusahaan yang tidak memenuhi kewajibannya dalam program BPJS di Kabupaten Malang? 


\section{Metode}

Penelitian ini menggunakan jenis penelitian yuridis empiris untuk mengkaji faktor-faktor penyebab tidak dikenakannya sanksi pidana terhadap perusahaan yang telah mendaftarkan peker- janya dalam program BPJS tetapi tidak memenuhi kewajibannya di Kabupaten Malang. Serta melakukan analisis terhadap implikasi hukum perusahaan yang tidak memenuhi kewajibannya dan upaya penegakan hukum pidana terhadap perusahaan yang tidak memenuhi kewajibannya se-

Tabel 1. Kepesertaan Program BPJS Kesehatan di Kabupaten Malang

\begin{tabular}{|c|c|c|c|c|c|c|}
\hline \multirow[t]{3}{*}{ Kecamatan } & \multicolumn{6}{|c|}{ Bukan Penerima Bantuan Iuran Jaminan Kesehatan (Non PBI) } \\
\hline & \multicolumn{3}{|c|}{$\begin{array}{l}\text { Pekerja Penerima Upah dan anggota } \\
\text { keluarganya }\end{array}$} & \multicolumn{3}{|c|}{$\begin{array}{c}\text { Bukan Penerima Upah dan anggota } \\
\text { keluarganya }\end{array}$} \\
\hline & Kelas I & Kelas II & Kelas III & Kelas I & Kelas II & Kelas III \\
\hline Donomulyo & 2087 & 10829 & 24 & 184 & 513 & 1357 \\
\hline Kalipare & 1555 & 4687 & 3 & 136 & 346 & 1028 \\
\hline Pagak & 1110 & 1520 & 9 & 125 & 313 & 918 \\
\hline Bantur & 1279 & 1520 & - & 137 & 382 & 1419 \\
\hline Gedangan & 1040 & 1014 & - & 104 & 261 & 760 \\
\hline Sumbermanjing & 135 & 1982 & 235 & 177 & 523 & 1613 \\
\hline Dampit & 2032 & 7630 & 25 & 358 & 828 & 2387 \\
\hline Tirtoyudo & 715 & 1134 & 85 & 136 & 300 & 801 \\
\hline Ampelgading & 889 & 1747 & 27 & 83 & 162 & 724 \\
\hline Poncokusumo & 1150 & 1834 & 6 & 88 & 309 & 904 \\
\hline Wajak & 1256 & 2569 & - & 164 & 383 & 1312 \\
\hline Turen & 4304 & 6573 & 10 & 563 & 1098 & 3684 \\
\hline Bululawang & 2223 & 7890 & 4 & 383 & 661 & 2336 \\
\hline Godanglegi & 1769 & 3629 & 16 & 226 & 645 & 2131 \\
\hline Pagelaran & 1391 & 1975 & - & 186 & 532 & 1532 \\
\hline Kepanjen & 5893 & 13409 & 4 & 919 & 1643 & 4039 \\
\hline Sumberpucung & 2440 & 3980 & - & 397 & 770 & 1821 \\
\hline Kromengan & 1294 & 2058 & 42 & 208 & 498 & 1038 \\
\hline Ngajum & 1009 & 2479 & - & 67 & 233 & 753 \\
\hline Wonosari & 884 & 1530 & 61 & 153 & 365 & 887 \\
\hline Wagir & 2168 & 15435 & - & 161 & 477 & 1605 \\
\hline Pakisaji & 3155 & 11199 & 2 & 429 & 1039 & 2625 \\
\hline Tajinan & 1106 & 4623 & 1 & 100 & 362 & 1244 \\
\hline Tumpang & 2014 & 3490 & 2 & 259 & 507 & 1433 \\
\hline Pakis & 6011 & 14076 & 1 & 954 & 1520 & 3257 \\
\hline Jabung & 884 & 3494 & - & 100 & 362 & 1244 \\
\hline Lawang & 7266 & 15479 & 288 & 1102 & 1534 & 4837 \\
\hline Singosari & 9114 & 25511 & 269 & 1296 & 2085 & 7038 \\
\hline Karangploso & 3104 & 8121 & 2 & 527 & 899 & 2453 \\
\hline Dau & 4056 & 5947 & 5 & 955 & 1005 & 2189 \\
\hline Pujon & 1005 & 3161 & - & 142 & 332 & 763 \\
\hline Ngantag & 1237 & 5426 & 370 & 141 & 355 & 999 \\
\hline Kasembon & 767 & 1396 & - & 120 & 148 & 505 \\
\hline & 78012 & 199015 & 1491 & 11071 & 21228 & 61362 \\
\hline
\end{tabular}

Sumber: BPJS Kesehatan Kabupaten Malang. 


\section{Jurnal Cakrawala Hukum, Volume 10 No. 2 Desember 2019}

ISSN PRINT 2356-4962 ISSN ONLINE 2598-6538

bagai peserta BPJS. Lokasi penelitian ini adalah di Kabupaten Malang, dipilih oleh penulis karena lokasi tersebut merupakan salah satu daerah yang memiliki potensi industri dan perdagangan yang besar.

Dalam penelitian empiris terdapat dua jenis data yaitu data primer dan data sekunder. Data primer dalam penelitian empiris adalah data yang bersumber dari penelitian lapangan yaitu suatu data yang diperoleh langsung dari sumber pertama di lapangan baik dari respoden maupun informan.

Data primer dalam penelitian empiris bersumber pada data yang diambil langsung dari lapangan atau bersumber langsung dari responden yang ditentukan oleh penulis yang nantinya diadakan wawancara dengan stakeholder terkait dengan penyelenggaraan BPJS dan penegakan hukum BPJS di Kabupaten Malang yakni BPJS Kesehatan Kabupaten Malang, BPJS Ketenagakerjaan Kabupaten Malang, Polres Kabupaten Malang, Dinas Ketenagakerjaan Kabupaten Malang. Selain itu juga data primer juga diambil langsung dari responden yakni peserta BPJS antara lain perusahaan dan juga pekerja di Kabupaten Malang.

Data sekunder dalam penelitian ini adalah dokumen-dokumen resmi, arsip-arsip, dan bukubuku. Dalam penelitian ini teknik pengumpulan data yang dilakukan penulis adalah wawancara. Wawancara adalah salah satu teknik pengumpulan data yang bisa digunakan dalam penelitian untuk mendapatkan informasi tentang obyek penelitian dengan cara mengajukan pertanyaan-pertanyaan secara lisan.

\section{Pembahasan}

a. Faktor-Faktor Penegakan Hukum Pidana Perusahaan yang Tidak Memenuhi Kewajibannya dalam Program BPJS

Kepesertaan perusahaan dalam program BPJS Kesehatan di Kabupaten Malang dalam penelitian ini ialah kelompok Non PBI yang terdiri dari Pekerja Penerima Upah dan anggota keluarganya, dan Pekerja Bukan Penerima Upah dan anggota keluarganya. Berikut ini merupakan tabel kepesertaan program BPJS Kesehatan di Kabupaten Malang (Data Statistik BPJS Kabupaten Malang, 2017):

Tingkat kepatuhan terhadap kewajiban sebagai peserta program BPJS Kesehatan dan BPJS Ketenagakerjaan yaitu memungut, menyetor dan membayar iuran yang menjadi beban peserta dari pekerjanya kepada BPJS. Menurut data Dinas Ketenagakerjaan Kabupaten Malang, per 31 April 2019, terdapat 249 perusahaan yang belum melakukan kewajibannya sebagai peserta program BPJS Kesehatan maupun BPJS Ketenagakerjaan (Wardoyo, 2019). Berikut ini merupakan rincian perusahaan yang tidak melakukan kewajibannya sebagai peserta BPJS (Wardoyo, 2019):

Berdasarkan data tersebut, terdapat 249 perusahaan dari 868 perusahaan yang terdaftar dalam program BPJS. Sehingga, terdapat $28,68 \%$ per-

Tabel3.2.Tingkat Ketidakpatuhan Perusahaan Sebagai Peserta Program BPJS di Kabupaten Malang

\begin{tabular}{|c|c|c|c|}
\hline $\begin{array}{l}\text { Keterlambatan } \\
\text { (dalam bulan) }\end{array}$ & Keterangan & Jumlah Perusahaan & Rincian Tunggakan \\
\hline $1-3$ & Lancar & 136 & Rp. 327.538.417,- \\
\hline $4-6$ & Kurang lancar & 26 & Rp. 84.687.947,- \\
\hline $7-12$ & Diragukan & 44 & Rp. 265.842.798,- \\
\hline$>12$ & Macet & 43 & Rp. 1.002.075.106,- \\
\hline Total & & 249 & Rp. 1.680.084.268,- \\
\hline
\end{tabular}

Sumber: Dinas Ketenagakerjaan Kabupaten Malang (diolah: 2019) 


\section{Penegakan Hukum Pidana Perusahaan yang Tidak Memenuhi Kewajibannya...}

Didik Lestariyono, Bambang Sugiri, Rachmad Syafa'at

usahaan yang tidak memenuhi kewajibannya sebagai peserta BPJS atau dengan kata lain telah memenuhi unsur Pasal 55 jo. Pasal 19 ayat (1) dan ayat (2) UU BPJS.

Menurut Soerjono Soekanto, tolak ukur penegakan hukum dipengaruhi oleh lima hal antara lain faktor hukum, faktor penegak hukum, faktor sarana dan fasilitas pendukung, faktor masyarakat dan faktor kebudayaan. Dalam faktor hukum, kepastian hukum pemenuhan kewajiban perusahaan dalam ketentuan yang terkandung dalam Pasal 19 ayat (1) dan ayat (2) UU BPJS. Perusahaan yang tidak memenuhi kewajibannya ialah sanksi pidana dalam Pasal 55 UU BPJS. Namun, ketentuan tersebut seakan mati di atas kertas. Ketentuan sanksi pidana yang terkandung dalam UU BPJS tidak mampu memberikan efek kepatuhan bagi perusahaan sebagai peserta program BPJS untuk memungut, menyetor dan membayar iuran BPJS pekerjanya.

Pelanggaran Pasal 19 ayat (1) dan ayat (2) mempunyai beberapa kategori/tingkatan sesuai dengan lamanya pemenuhan kewajiban perusahaan. Kategori tersebut antara lain (Wardoyo, 2019):

Dalam praktiknya, pelanggaran Pasal 19 ayat (1) dan ayat (2) mempunyai beberapa kategori/ tingkatan sesuai dengan lamanya pemenuhan kewajiban perusahaan. Kategori tersebut antara lain (Wardoyo, 2019): a. Lancar, perusahaan melakukan keterlambatn dalam 1-3 bulan; b. Kurang lancar, perusahaan melakukan keterlambatan dalam 4-6 bulan; c. Diragukan, perusahaan melakukan keterlambatan 7-12 bulan; dan d. Macet, perusahaan melakukan keterlambatan $>12$ bulan.

Ketentuan mengenai kewajiban perusahaan sebagai peserta program BPJS. Undang-undang tidak memberikan pengertian yang jelas mengenai pemenuhan kewajiban tersebut dilakukan pada saat tagihan jatuh tempo atau perusahaan boleh terlambat dalam pemenuhannya. Dengan melihat frasa dalam Pasal 19 ayat (1) dan ayat (2) tentu semua perusahaan yang terlambat satu hari pun dapat dikenakan sanksi pidana dalam Pasal 55 UU BPJS. Karena telah memenuhi unsur tidak memungut, menyetor dan membayar iuran yang menjadi kewajibannya.

Faktor Penegak Hukum, dalam berfungsinya hukum, mentalitas atau kepribadian petugas penegak hukum memainkan peranan penting, kalau peraturan sudah baik, tetapi kualitas petugas kurang baik, ada masalah (Wardoyo, 2018). Kepala Unit Tindak Pidana Tertentu Kepolisian Resor Kabupaten Malang mengungkapkan bahwa sampai saat ini belum terdapat penanganan ataupun pengaduan dari masyarakat atau penyelenggara BPJS terkait tidak dipenuhinya kewajiban perusahaan sebagai peserta dalam program BPJS di Kabupaten Malang (Hartawan, 2019). Agung Hertawan, mengungkapkan memang upaya represif melalui penegakan hukum pidana merupakan upaya terakhir dan disebut dengan ultimum remedium (Rochmad, 2015). Upaya ini baru diberikan ketika upaya-upaya lain tidak mampu menyelesaikan permasalahan.

Senada dengan hal tersebut, Kepala Cabang BPJS Ketenagakerjaan Kabupaten Malang mengungkapkan saat ini pihak penyelenggara BPJS Ketenagakerjaan berusaha untuk memenuhi target kepesertaan yang setiap tahun mengalami peningkatan (Hariyanto, 2019). Adapun untuk perusahaan yang telah menjadi peserta kemudian tidak melaksanakan Pasal 19 ayat (1) dan ayat (2) pihak penyelenggara BPJS Ketenagakerjaan melakukan dua upaya yaitu upaya preventif dan upaya represif.

Faktor sarana dan fasilitas pendukung, faktor ini menjadi salah satu penyebab ketaatan perusahaan karena kemajuan teknologi yang sedemikian rupa membantu dan mempermudah perusahaan dalam memenuhi kewajibannya. Pemenuhan kewajiban perusahaan sebagai peserta dapat dilakukan dengan mudah melalui media pembayaran yang beragam (Rahayu, 2019).

Faktor masyarakat, perusahaan yang tidak memenuhi kewajibannya dikarenakan manajemen 


\section{Jurnal Cakrawala Hukum, Volume 10 No. 2 Desember 2019}

ISSN PRINT 2356-4962 ISSN ONLINE 2598-6538

perusahaan yang tidak menganggap penting pemenuhan jaminan kesehatan dan jaminan sosial pekerjanya. Manajemen telah memotong gaji pekerjanya perbulan, namun tidak disetorkan dan dibayarkan kepada BPJS, melainkan digunakan untuk menunjang operasional perusahaan dan ekspansi perusahaan agar lebih besar (Widiyanto, 2019).

Perusahaan yang memenuhi kewajiban disebabkan karena faktor kesadaran hukum yaitu memahami adanya sanksi pidana yang dapat dikenakan kepada perusahaan apabila tidak memenuhi kewajibannya berupa memungut, menyetor dan membayar iuran BPJS pekerjanya. Selain itu, terdapat faktor internal dari perusahaan itu sendiri yakni kedisiplinan dari manajemen perusahaan dalam mengelola keuangan salah satunya penggunaan iuran BPJS yang seharusnya disetorkan ke BPJS Kesehatan dan BPJS Ketenagakerjaan (Rahayu, 2019). Yang kedua ialah tidak adanya sikap dari pekerja aktif menanyakan atau menuntut perusahaan untuk memenuhi kewajibannya yaitu menyetor dan membayar iuran dalam program BPJS. Terakhir ialah faktor kebudayaan, pada dasarnya mencakup nilai-nilai yang mendasari hukum yang berlaku, nilai-nilai mana yang merupakan konsepsi-konsepsi yang abstrak mengenai apa yang dianggap baik (sehingga dituruti) dan apa yang dianggap buruk (sehinga dihindari). Kesadaran hukum merupakan kesadaran atau nilai-nilai yang terdapat di dalam diri manusia, tentang hukum yang ada atau tentang hukum yang diharapkan ada (Heryani, 2012). Pengertian lain mengenai kesadaran hukum, dijelaskan oleh Soerjono Soekanto bahwa kesadaran hukum itu merupakan persoalan nilai-nilai dan konsepsi-konsepsi abstrak yang terdapat dalam diri manusia, tentang keserasian antara ketertiban dan ketentraman yang dikehendaki atau sepantasnya (Mas, 2014).

Perusahaan yang memenuhi kewajiban disebabkan karena faktor kesadaran hukum yaitu memahami adanya sanksi pidana yang dapat dikenakan kepada perusahaan apabila tidak memenuhi kewajibannya berupa memungut, menyetor dan membayar iuran BPJS pekerjanya. Selain itu, terdapat faktor internal dari perusahaan itu sendiri yakni kedisiplinan dari manajemen perusahaan dalam mengelola keuangan salah satunya penggunaan iuran BPJS yang seharusnya disetorkan ke BPJS Kesehatan dan BPJS Ketenagakerjaan (Rahayu, 2019).

Kesadaran hukum merupakan kesadaran atau nilai-nilai yang terdapat di dalam diri manusia, tentang hukum yang ada atau tentang hukum yang diharapkan ada (Heryani, 2019). Pengertian lain mengenai kesadaran hukum, dijelaskan oleh Soerjono Soekanto bahwa kesadaran hukum itu merupakan persoalan nilai-nilai dan konsepsi-konsepsi abstrak yang terdapat dalam diri manusia, tentang keserasian antara ketertiban dan ketentraman yang dikehendaki atau sepantasnya (Mas, 2014). Kesadaran hukum mempunyai beberapa konsepsi, salah satu diantaranya adalah konsepsi mengenai kebudayaan hukum. Konsepsi ini mengandung ajaran-ajaran kesadaran hukum yang lebih banyak mempermasalahkan kesadaran hukum yang dianggap sebagai mediator antara hukum dengan perilaku manusia, baik secara individual maupun kolektif.

Selanjutnya, penulis menguraikan faktorfaktor yang mempengaruhi perusahaan tidak memenuhi kewajibannya sebagai peserta dalam program BPJS. Perusahaan yang tidak memenuhi kewajibannya dipengaruhi oleh faktor internal dan faktor eksternal. Faktor internal dikarenakan manajemen perusahaan yang tidak menganggap penting pemenuhan jaminan kesehatan dan jaminan sosial pekerjanya. Manajemen telah memotong gaji pekerjanya perbulan, namun tidak disetorkan dan dibayarkan kepada BPJS, melainkan digunakan untuk menunjang operasional perusahaan dan ekspansi perusahaan agar lebih besar (Widiyanto, 2019).

Selain dari manajemen, faktor internal yang lain ialah tidak adanya sikap dari pekerja aktif menanyakan atau menuntut perusahaan untuk 


\section{Penegakan Hukum Pidana Perusahaan yang Tidak Memenuhi Kewajibannya...}

Didik Lestariyono, Bambang Sugiri, Rachmad Syafa'at

memenuhi kewajibannya yaitu menyetor dan membayar iuran dalam program BPJS. Hal ini tentu saja mengganggu stabilitas dan kenyamanan pekerja dalam bekerja di perusahaan (Wodoanto, 2019). Adapun faktor eksternal yaitu banyaknya perusahaan yang juga tidak membayar iuran BPJS namun tidak dikenakan sanksi pidana, melainkan sanksi administrative (Hariyanto, 2019). Padahal, Pasal 55 UU BPJS sudah jelas memberikan sanksi pidana bagi perusahaan peserta program BPJS yang tidak memenuhi kewajibannya sebagaimana dimaksud dalam Pasal 19 ayat (1) dan ayat (2). Adapun untuk sanksi administratif seharusnya diberikan kepada perusahaan yang belum mendaftarkan diri dalam program BPJS Kesehatan maupun BPJS Ketenagakerjaan. Sehingga, membuat perusahaan yang telah terdaftar ikut "membandel" dengan tidak memenuhi kewajibannya sebagai peserta dalam program BPJS.

\section{b. Implikasi Hukum Perusahaan yang Tidak Memenuhi Kewajibannya dalam Program BPJS}

Implikasi hukum berupa sanksi pidana tersebut tidak diterapkan dalam penyelenggaraan program BPJS di Kabupaten Malang. Hal ini dikarenakan belum adanya tindakan represif dari stakeholder terkait dan aparat penegak hokum (Hariyanto, 2019). Walaupun dalam praktiknya terdapat perusahaan yang memenuhi unsur-unsur dalam Pasal 55 jo. Pasal 19 ayat (1) dan ayat (2) UU BPJS.

Kepastian hukum pemenuhan kewajiban perusahaan dalam program BPJS, penulis melakukan analisis terhadap faktor hukum yang menjadi landasan penyelenggaraan program BPJS. Ketentuan yang menjadi dasar kewajiban perusahaan dalam program BPJS terkandung dalam Pasal 19 ayat (1) dan ayat (2). Adapun implikasi bagi perusahaan yang tidak memenuhi kewajibannya ialah sanksi pidana dalam Pasal 55 UU BPJS. Namun, seakan mati di atas kertas. Ketentuan tersebut tidak mam- pu memberikan efek kepatuhan bagi perusahaan sebagai peserta program BPJS untuk memungut, menyetor dan membayar iuran BPJS pekerjanya.

Dalam ketentuan mengenai kewajiban perusahaan sebagai peserta program BPJS. Undangundang tidak memberikan pengertian yang jelas mengenai pemenuhan kewajiban tersebut dilakukan pada saat tagihan jatuh tempo atau perusahaan boleh terlambat dalam pemenuhannya. Dengan melihat frasa dalam Pasal 19 ayat (1) dan ayat (2) tentu semua perusahaan yang terlambat satu hari pun dapat dikenakan sanksi pidana dalam Pasal 55 UU BPJS. Karena telah memenuhi unsur tidak memungut, menyetor dan membayar iuran yang menjadi kewajibannya.

Oleh karena dalam praktiknya banyak perusahaan dan beragam pemenuhan kewajibannya (keterlambatannya), pembuat kebijakan perlu melakukan revisi atau penambahan penjelasan mengenai kewajiban yang seharusnya dilakukan perusahaan dalam Pasal 19 ayat (1) dan ayat (2) UU BPJS. Sehingga, baik stakeholder terkait yaitu BPJS Kesehatan, BPJS Ketenagakerjaan dan Dinas Ketenagakerjaan serta Kepolisian mampu memberikan sanksi pidana secara tepat. Karena dengan tidak adanya indikator keterlambatan perusahaan dalam pemenuhan kewajiban sebagai peserta BPJS, perusahaan tidak merasa jera karena telah terlambat memenuhi kewajiban sebagai peserta BPJS. Padahal, hak-hak pekerja berupa jaminan kesehatan dan jaminan sosial harus setiap saat dibutuhkan oleh pekerja dan penerima manfaat lainnya (keluarga pekerja).

Terdapat $26,68 \%$ perusahaan yang sudah menjadi peserta BPJS namun tidak memenuhi kewajibannya sehingga berdampak pada tunggakan iuran BPJS sebesar Rp. Rp. 1.680.084.268,- (satu miliar enam ratus delapan puluh juta delapan puluh empat ribu dua ratus enam puluh delapan rupiah). Tentu, ketidakpatuhan perusahaan terhadap kewajibannya berakibat pada jaminan kesehatan dan jaminan sosial pekerja menjadi terganggu apabila 


\section{Jurnal Cakrawala Hukum, Volume 10 No. 2 Desember 2019}

ISSN PRINT 2356-4962 ISSN ONLINE 2598-6538

hendak melakukan klaim di BPJS. Sehingga, tindakan-tindakan perusahaan yang tidak memenuhi kewajiban sebagai peserta BPJS menghalangi semangat perwujudan kesejahteraan rakyat melalui sistem jaminan sosial nasional (SJSN) agar memberikan kepastian perlindungan dan kesejahteraan sosial bagi seluruh rakyat Indonesia.

Sehingga, untuk tetap menjaga kepatuhan perusahaan tempat pekerja bekerja memenuhi kewajibannya dalam program BPJS di Kabupaten Malang. Pekerja dapat melakukan upaya preventif dan upaya represif. Upaya preventif dapat dilakukan dengan menginformasikan kepada pihak yang berwenang untuk memungut iuran BPJS dari gaji masing-masing pekerja sesuai dengan waktu jatuh tempo pembayaran program BPJS. Dengan mengingatkan dan menginformasikan maka pihak perusahaan mempunyai rasa tanggung jawab dan disiplin dalam pemenuhan kewajiban sebagai peserta program BPJS Kesehatan dan/atau Ketenagakerjaan. Adapun upaya represif yang dapat dilakukan oleh pekerja ialah dengan melaporkan kepada pihak yang berwenang yaitu Kepolisian atas pelanggaran Pasal 19 ayat (1) dan ayat (2) jo. Pasal 55 UU BPJS. Dengan pengaduan kepada pihak kepolisian, diharapkan memberikan efek jera kepada perusahaan.

\section{Simpulan}

Faktor penyebab perusahaan tidak memenuhi kewajiban sebagai peserta dalam program BPJS yaitu faktor internal dan faktor eksternal. Faktor internal dikarenakan tidak disiplinnya perusahaan dalam mengelola keuangan yang seharusnya digunakan sebagai iuran program BPJS pekerjanya. Sedangkan faktor eksternal yaitu dikarenakan BPJS Kesehatan Kabupaten Malang, BPJS Ketenagakerjaan Kabupaten Malang, Dinas Ketenagakerjaan Kabupaten Malang hanya memberikan sanksi administratif kepada perusahaan yang tidak memenuhi kewajibannya sebagai peserta program
BPJS. Pemberian sanksi administratif dilakukan agar investor tidak takut melakukan kegiatan usahanya di Kabupaten Malang. Selain itu, pekerja sebagai penerima manfaat dari program BPJS takut melaporkan perusahaan yang tidak memenuhi kewajibannya.

Implikasi hukum bagi perusahaan yang tidak memenuhi kewajibannya sebagai peserta program BPJS sebagaimana diatur dalam Pasal 19 ayat (1) dan ayat (2) UU BPJS ialah dikenakan sanksi administratif oleh BPJS Kesehatan Kabupaten Malang, BPJS Ketenagakerjaan Kabupaten Malang dan Dinas Ketenagakerjaan Kabupaten Malang.

\section{Daftar pustaka}

Badan Pusat Statistik Kabupaten Malang. 2017. Hasil Pendaftaran (Listing) Usaha/Perusahaan Sensus Ekonomi 2016 No 1/06/3507/Th. I, 12 Juni. Malang. BPS Kabupaten Malang.

Badan Pusat Statistik Kabupaten Malang. 2017. Kabupaten Malang Dalam Angka 2017. Malang. BPS Kabupaten Malang.

BPJS Kesehatan Kabupaten Malang. 2017. Dalam Badan Pusat Starisrik, Kabupaten Malang Dalam Angka 2017. Malang. BPS Kabupaten Malang.

Hariyanto. 2019. Hasil Wawancara. Kepala Cabang BPJS Ketenagakerjaan Kabupaten Malang, pada tanggal 14 Mei 2019.

Hertawan, Agung. 2019. Hasil Wawancara. Kepala Unit 2 (Tindak Pidana Tertentu) Polres Kabupaten Malang pada tanggal 6 Mei 2019.

Heryani, Wiwie dan Achmad Ali. 2012. Menjelajahi Kajian Empiris Terhadap Hukum. Jakarta. Kencana.

Hitaningtyas, Ratih Dheviana Puru. 2017. Penghapusan Sanksi Pidana Terkait Kewajiban Pemberi Kerja Untuk Mengikutsertakan Pekerjanya Dalam Program Jaminan Sosial. Jurnal Panorama Hukum. Vol. 2 No 1 Juni 2017 Fakultas Hukum Universitas Kanjuruhan Malang,(http://ejournal.unikama.ac.id/ index.php/jph/article/view/1753) Diakses pada tanggal 12 September 2018 pukul 10.00 WIB, Panorama Hukum. Universitas Kanjuruhan Malang. 


\section{Penegakan Hukum Pidana Perusahaan yang Tidak Memenuhi Kewajibannya...}

Didik Lestariyono, Bambang Sugiri, Rachmad Syafa'at

Huijbers, Theo. 1999. Filsafat Hukum. Yogjakarta. Kanisius.

JatimTimes.com. 2018. 60 Persen Perusahaan di Kabupaten Malang Tidak Patuh Bayar BPJS. https:// www.jatimtimes.com, diakses pada tanggal 11 Agustus 2018 pukul 19.00 WIB.

Malang Post. 2018. 60 Persen Perusahaan Tidak Taat Bayar BPJS. https://www.malang-post.com. diakses pada tanggal 11 Agustus 2018 pukul 19.00 WIB.

Mas, Marwan. 2014. Pengantar Ilmu Hukum. Bandung. Ghalia Indonesia. Bogor.

Muhammad, Abdulkadir. 2006. Hukum Perusahaan Indonesia. Bandung. Citra Aditya Bakti.

Pemerintah Kabupaten Malang. 2015. Potensi Industri. http:// www.malangkab.go.id. diakses pada tanggal 12 September 2018 pukul 8.52 WIB.

Peraturan Pemerintah RI Nomor 86 Tahun 2013 tentang Tata Cara Pengenaan Sanksi Administratif Kepada Pemberi Kerja Selain Penyelenggara Negara dan Setiap Orang, Selain Pemberi Kerja, Pekerja, dan Penerima Bantuan Iuran Dalam Penyelenggaraan Jaminan Sosial. (LN RI Tahun 2013 Nomor 238, TLN RI Nomor 5481)
Rahayu, Hastari Ajeng Mukti. 2019. Hasil Wawancara. Manajer PT. Temprina Media Grafika Malang pada tanggal 13 Mei 2019.

Said, M. Natzir. 1987. Hukum Perusahaan di Indonesia I (Perorangan). Alumni..

Syafa'at, Rachmad. 2008. Negara, Masyarakat Adat dan Kearifan Lokal. Yogjakarta. In-Trans Pub.

Undang-Undang Nomor 24 Tahun 2011 tentang Badan Penyelenggara Jaminan Sosial.(LN RI Tahun 2011 Nomor 116, TLN RI Nomor 5256)

Undang-Undang Nomor 40 Tahun 2004 tentang Sistem Jaminan Sosial Nasional. (LN RI Tahun 2004 Nomor 150, TLN RI Nomor 4456)

Wardoyo, Yoyok. 2019. Hasil Wawancara. Kepala Dinas Ketenagakerjaan Kabupaten Malang. pada tanggal 31 April 2019.

Wardoyo, Yoyok. 2019. Hasil Wawancara. Kepala Dinas Ketenagakerjaan Kabupaten Malang, pada tanggal 31 April 2019.

Widiyanto, Irfan. 2019. Hasil Wawancara. Manajer HRD PT. Repoeblik Telo pada tanggal 2 Mei 2019. 